\title{
The Author Disappearing? Authorial "Surrogates" and Contemporary Self/Other-Writing in Selected Works by Annie Ernaux, Édouard Louis, and Rachel Cusk
}

\author{
Robert Kusek \\ Department of Comparative Studies in Literature and Culture \\ Institute of English Studies \\ Jagiellonian University in Kraków \\ robert.kusek@uj.edu.pl
}

Received 18 March 2021; accepted 9 September 2021; published 20 September 2021.

\begin{abstract}
The aim of this paper is to investigate various diegetic gestures of deliberate and insistent selferasure - quite conspicuous in the age of the authors' glorious "return" and their hyper-visibility - which the essay wishes to identify as testifying to some countertendencies in presentday auto/biographical writing. The return of the author, officially acknowledged in the final decade of the twentieth century, resulted in contemporary writers unanimously and abundantly engaging themselves in narrating their real life stories - the phenomenon which prompted an unprecedented emergence of writers' auto/biographical narratives at the turn of the twentyfirst century. Nevertheless, in recent years this authorial resurrection has also led to the rise of some new forms of self-writing which might be seen not only as a means of expressing one's dissatisfaction with the present-day auto/biographical boom but also a manifestation of the crisis of both the auto/biographical self and form. These new self-narratives consciously play with the idea of authorship and question the principles of straightforward representation of the historical author in their literary production. The paper will analyse selected contemporary self-narratives (i.e. Annie Ernaux's Les Années [2008], Édouard Louis's En finir avec Eddy Bellegueule [2014], and Rachel Cusk's “Fay” trilogy, which comprises Outline [2014], Transit [2016], and Kudos [2018]) so as to investigate the authors' "surrogates" and thus the emergence of a new poetics of self/other-writing.
\end{abstract}

Keywords: author surrogate; autofiction; self/other-writing; Annie Ernaux; Édouard Louis; Rachel Cusk 
I just use myself as the material and, given that it hasn't sold very many books, I want no more of that exposure. (Cusk as cited in Wade, 2015)

For a paper which wishes to address the notions of authorial disappearance and author surrogacy in contemporary literary practices, it seems impossible not to start with a book that over the last few years has problematised the very idea of authorship like no other recent work of fiction or non-fiction. Elena Ferrante's first volume of the Neapolitan Novels ${ }^{1}$ opens with a mysterious vanishing of Rafaella Cerullo (called Lina, or Lila), the titular "brilliant friend" of the series' narrator, the author's namesake Elena Greco (also called Lenuccia and Lenù). The latter, who lives in Turin, receives a morning call from Rino, Lila's son, who informs her that his mother "is gone" (Ferrante, 2012, loc. 42). Lila's disappearance at the age of sixty-six is a radical attempt not only to erase herself but also her entire life and its many tangible traces: dresses, shoes, books, photographs, computer disks, birth certificates, bills, and receipts - not to mention the act of cutting herself out of all the photographs that have been left behind. As noted by Elena (the character), not a "single hairpin that belongs to her" (loc. 54) is to be found by Rino, who is desperately looking for any piece of evidence that would confirm his mother's existence. "She has found a way to disappear, to leave not so much as a hair anywhere in this world," the narrator concludes (loc. 49).

However, the act of disappearing pertains not only to a fictional character but also to the author herself (or himself) who - despite the book's overt auto/biographical indicators - has famously refused to reveal her/his identity and continues - even after several attempts to "unmask" her/him, including an investigation carried out by Claudio Gatti (2016), who resorted to the use of forensic accounting so as to trace and "identify" Ferrante ${ }^{2}$ - to remain a major enigma in the present-day book industry.

Ferrante's gesture of deliberate (and insistent) self-erasure - quite conspicuous in the age of the authors' glorious "return" and their hyper-visibility - is, I believe, not only intriguing in its own right but also illustrative of some significant countertendencies in contemporary writing - auto/biographical writing in particular. It is certainly no coincidence that only when the return of the author was officially acknowledged (as eloquently demonstrated by Seán Burke's

\footnotetext{
${ }^{1}$ This best-selling series known in Italian as L'amica genial comprises four volumes: L'amica geniale (2011; English translation: My Brilliant Friend, 2012), Storia del nuovo cognome (2012; English translation: The Story of a New Name, 2013), Storia di chi fugge e di chi resta (2013; English translation: Those Who Leave and Those Who Stay, 2014), Storia della bambina perduta (2014; English translation: The Story of the Lost Child, 2015).

${ }^{2}$ Gatti claims that Ferrante is a pseudonym of the Rome-based translator Anita Raja, the wife of the Neapolitan writer Domenico Starnone (2016). In 2018, having used a number of computer-based authorship attribution methods, the Swiss linguist Jacques Savoy declared that Domenico Starnone is the true author behind Elena Ferrante's pen name (2018, p. 916).
} 
seminal study The Death and Return of the Author [1992] $\left.]^{3}\right)$, did contemporary writers unanimously and abundantly engage themselves in narrating their real life stories, which led to an unprecedented (qualitatively speaking) emergence of writers' auto/biographical narratives (memoirs, biographies, letters, diaries, etc.) at the turn of the twenty-first century. If at the beginning of the 1990s the author/writer, considered by post-structuralism to be "the decrepit deity of the old criticism" (Barthes, 1979, p. 211), started "speak[ing] strangely to us [...] through the fissures of seemingly impersonal and imperturbable prose" (Burke, 1992, p. 7), more than a quarter of a decade later the very same author - understood as the "historical author," namely a historical agent who has produced an original textual artefact ${ }^{4}$ - is not only powerfully back and alive (both conceptually and pragmatically) but, most importantly, more than willing to write some very personal prose. And (s)he is again the very focus of critical and readerly attention.

Nevertheless, in recent years, as Elena Ferrante's case clearly proves, this authorial resurrection which coincides with the arrival of the auto/biographical turn in the humanities and social science has led to the rise of some new forms of self-writing - alongside a plethora of writers' auto/biographical narratives that have religiously complied with the canonical (i.e. Lejeunian [1989a, p. 7]) form of autobiography characterised by the equation author=narrator=character, and with the principle of truth-telling. They might be seen not only as a means of expressing one's dissatisfaction with the dominant modes and genres of the present-day life-writing boom, ${ }^{5}$ but also a manifestation of the crisis of the auto/biographical self and form. These new self-narratives consciously play with the idea of authorship and question the principles of straightforward representation of the authorial self, the historical author, in their literary production.

In 2018 alone, several major volumes of such insurgent self-narratives were released in English-speaking countries: Sight by Jessie Greengrass, Motherhood by Sheila Heti, and Crudo by Olivia Laing (all three subtitled "A Novel”), Break.up by Joanna Walsh (subtitled "A Novel in Essays"), and The Cost of Living by Deborah Levy (subtitled "A Working Autobiography"). It was also in 2018 that Rachel Cusk published Kudos, the final volume of her critically-acclaimed and highly influential "autofictional" trilogy, while Fitzcarraldo Editions released the English translation of Annie Ernaux's “collective autobiography” Les Années, origi-

\footnotetext{
${ }^{3}$ A comprehensive account of the author's return in the last two decades of the twentieth century can also be found in Seán Burke's Authorship. From Plato to the Postmodern. A Reader (2003) and Andrew Bennett's The Author (2005).

4 "The historical author of the text is the person responsible for the features which make a text different from other texts. The historical author creates a text insofar as he produces a textual artefact that is different from all other textual artefacts either in meaning, syntactical arrangement, or sign-type composition" (Garcia,1996, p. 110). Garcia's category of an originator/cause of the text remains (essentially) synonymous with what Alexander Nehamas defines simply as the "writer" (2002, pp. 95-115), while H.L. Hix uses the term "creative author" (1991, p. 39).

${ }^{5}$ On the present-day "golden age of life writing boom," also known as "memoir boom" or "biography boom," kindly consult Kusek (2017, p. 14). Cf. Rak 2013.
} 
nally published in France in 2008. Finally, it was in 2018 that the English-language readers of Karl Ove Knausgård's My Struggle were introduced to the sixth and final volume of his book series, tellingly subtitled "The End."

As already stipulated, it is more than justifiable to insist that what the above-listed books have in common is substantially more than just the date of their official release, and that they, in fact, testify to the arrival of a new literary zeitgeist. For example, they have all been variably called (e.g. Schmitt and Kjerkegaard, 2016; Ali, 2017) revolutionary, radical, and experimental, to list but a few of the evaluative adjectives typically attributed to them and emphasising their innovativeness and originality, especially when approached from the point of view imposed by a diachronic study of Western literature. They have all troubled their critics and readers as far as their generic identity is concerned (Elkin, 2018). Making thematic, modal, and formal markers, which traditional genre theory finds instrumental in defining a specific generic affiliation, highly ambiguous and indeterminate, they have invited multiple classifications and challenged their "pure" generic positions. Ostensibly resisting the "laws" of auto/biographical writing - despite embracing real-life events from the authors' lives - and voicing their discontent with the present-day memoir boom (e.g. Heti and Cusk, 2018), their creators have been seen as the avant-garde of a new mode of creative writing and harbingers of the novel's latest incarnation (in the wake of the auto/biographical turn) (Lowdon, 2018). At the same time, they have been criticised by the defenders of fiction for not "making things up" anymore (Clark, 2018), for their determination to expose and probe the limits of fiction, as well as for deliberate use of their own life stories, and thus for further contributing to putting the novel at stake.

Among the critics that have recently attempted to address the phenomenon of this new selfwriting and answer the many questions that it has provoked over the last few years, Fredric Jameson's succinct yet sharp analysis appears to be particularly relevant to the present paper and its interest in the liaison between authorship and life narratives. In his essay entitled "Itemised," published in London Review of Books in November 2018 and dedicated to the final volume of Karl Ove Knausgård's My Struggle, Jameson ponders over a number of characteristics that distinguish Knausgård's works ${ }^{6}$ from the present-day literary production. Having declared an unproductivity of the terms autobiography and fiction with regard to Knausgård's My Struggle - he calls it simply "something else" (though he hastens to remind one that "the French decided to call it 'autofiction' at one point" [Jameson 2018]) - he moves to discuss the series' differentiae specificae, namely openness (against truth-telling), itemisation, and establishing a new kind of author/reader relationship which he calls "being-for-the-reading-other." Still, he dedicates some special attention to the narrative's "constant preoccupation with the pronouns" which he links to "neurosis [being] the very structure of human subjectivity," as well as to the "hapless attempt of a biologically incomplete being to claim some mental or spiritual completeness" (Jameson, 2018).

\footnotetext{
${ }^{6}$ As well as works by Elena Ferrante and Roberto Bolaño - however, the list could certainly be extended to include all the writers and their "insurgent self-narratives" mentioned in the main body of the present essay.
} 
Having deliberately disregarded the validity, convincingness, and productivity of some of Jameson's claims - many of which are imprecise, elusive, and derivative - I should nevertheless like to acknowledge two aspects of his argument which I recognise as both legitimate and well-founded.

Firstly, I am more than willing to agree that these new works of self-writing powerfully challenge (and, in fact, incapacitate) critics' attempts at straightforward genre classification and that in the face of this notional/genetic/generic crisis one may be compelled to use a highly ambiguous (and largely hollow) phrase, i.e. "something else," while referring to them. Indeed, as Jameson accurately observes, for the lack of a better word/category, the most frequentlyemployed term (by critics, not necessarily readers) is that of "autofiction" - however, not the kind that was invented and practiced by the genre's originator Serge Doubrovsky, ${ }^{8}$ but autofiction understood more broadly, as "self-reflexive modalities that are excluded from the generic realm of 'formal' autobiography and call its pretentions and processes into question, or refuse to embrace them wholesale" (Hughes, 1999, p. 3). Undoubtedly, despite various voices of discontent and promotion of alternative categories (e.g. "self-narration" [Schmitt, 2010], "autobiografiction" [Saunders, 2010, p. 7]), autofiction has been increasingly favoured by contemporary scholarship concerned with unorthodox present-day life narratives. ${ }^{9}$ One of the reasons for prioritising it over other generic identities (alongside its ambiguity, generic indeterminacy, ${ }^{10}$ indebtedness to the avant-garde literary practices, standing in opposition the

\footnotetext{
${ }^{7}$ Philippe Vilain has recently observed (much to his chagrin) that "[F]ollowing fashion, we call 'autofiction' just about everything that has to do with autobiography generally" (2008, p. 6). On the differences between autobiography and autofiction kindly consult Ferreira-Meyers (2015, pp. 203-218).

${ }^{8}$ Serge Doubrovsky invented "autofiction" and provided its definition in 1977 upon publication of his novel Fils. On the back cover of the book, he wrote: "Autobiografie? Non. [...] Fiction d'événements et de faits strictement réels; si l'on veut, autofiction, d'avoir confié le langage d'une aventure à l'aventure de langage, hors sagesse et hors syntaxe du roman, traditionnel ou nouveau" (2001). According to Doubrovsky, a work of autofiction was supposed to have three essential parameters: "une écriture littéraire, une parfaite identité onomastique entre l'auteur, le narrateur et le héros, et une importance decisive accordée à la psychanalyse" (Gasparini, 2004, p. 12). When discussing his dissatisfaction with the term autofiction, Arnaud Schmitt has noted the following: "When [Doubrovsky] came up with the term autofiction, he was not looking at a theoretical dead end; he was trying to give a name to a very specific form of autobiographical expression" (2010, p. 126). This fact might be seen as encouraging one to resist the use of autofiction with regard to contemporary works discussed herein as they are deeply concerned with (and often result from) the novel's and auto/biography's dead end; in this sense, they are essentially post-auto/biographical/post-fictional works.

${ }^{9}$ Suffice it to mention that in 2018 Palgrave Macmillan published the first monograph to be fully dedicated to autofiction in English (Dix, 2018a), while in October 2019 Wolfson College, University of Oxford, organised a major academic conference which focused exclusively on contemporary autofiction ("Autofiction - Theory, Practices, Cultures - A Comparative Perspective," 19-20 October).

${ }^{10}$ Hywel Dix rightly argues that "there is no single definition of autofiction either in English or in French" (2018b, p. 2). However, one should note a number of important studies of autofiction in French which in recent years have helped to formulate a more comprehensive account of the genre and which seem to be consistently overlooked by scholars focusing exclusively on English-language literature: particularly Vincent's Colonna 2004 volume entitled Autofiction et autres mythomanies littéraires (and its original taxonomy, which recognises four sub-types of autofiction, namely l'autofiction fantastique, biographique, spéculaire, and intrusive/autoriale
} 
English literary tradition due to its French or continental origin) is the fact that autofiction is - perhaps more than any life-writing mode - profoundly preoccupied with the category of the auto/biographical author. As Marjorie Worthington has aptly put it:

[An] important effect of the autofictional novel is that it demonstrates the continued relevance of the author, despite theoretical arguments about his (and sometimes her) death. Far from being dead to these novels, the author is the protagonist within them. Furthermore, by requiring constant adjustment and readjustment of reader expectations as to what is factual about the author/character and what is fictional, autofiction requires a continual recognition of the presence and authority of the actual author. In other words, the figure of the extratextual author maintains a presence within the novel by requiring the reader to determine or at least to wonder - to what extent the author is equivalent to the author-character. (2017, p. 477)

More recently, in the wake of the event organised by the Centre for Modern Literature and Culture at King's College London, which brought together such "autofictionalists" as Rachel Cusk and Jessie Greengrass, Alice Attlee has thus re-affirmed the centrality of the author in contemporary English-language autofiction:

The genre's emphasis on real-life events, "strictly" recounted, firmly places the emphasis of a work onto one person: the author. Knowing whether the content of a book is indeed grounded in real-life experiences bears on the value of the work, and only the author can speak for the authenticity of what they have produced. Others might vouch for - or against certain moments in a book. Perhaps it is their anecdote being recounted, or their house being described; their relationship explored or their appearance portrayed. Yet only the author witnesses the creation of a book in its entirety. Autofiction, then, might be the genre in which the author holds most power over the reception of their work: in autofiction, it matters whether the author tells us something has actually happened, or claims to have simply made it up. There is a great deal of ego involved in placing oneself so explicitly at the centre of a narrative: as the protagonist, narrator and focalizer, all at once. (2019)

Regardless of their generic attribution, in other words whether one shall label them as specimens of autofiction or - as the present paper is inclined to do in the light of on-going and unresolved debates on autofiction's notional ambiguity, testified to by Jameson's "something else" phrase - to recognise them simply as instances of self-writing (this écriture de soi, also known as écriture $d u J e$ ), it remains unquestionable that one of the major objectives of the narratives addressed herein is, indeed, to expose, interrogate, and challenge the very integrity of the narrator/character/author relationship.

Secondly, I would argue, in line with Jameson's claims, that it is via two indexes, namely the notion of a person (defined by a grammatical criterion) and the position of the narrator (his or her relationship with what one can call a given text's major character, as well their point of 
view $^{11}$ ) that the notion of authorship in the aftermath of the auto/biographical turn becomes particularly problematised. Consequently, what I should like to do in this part of the paper is to briefly discuss several idiosyncratic strategies employed by selected contemporary authors to write (and at the same time refuse to write) about the lives of (their) selves. In other words, I should like to briefly focus on three, chronologically arranged instances of self-writing (or works of autofiction ${ }^{12}$ ) that explore the authorial disappearance and the question of their diegetic surrogacy precisely via their very special "preoccupation" - to use Jameson's expression - with pronouns, proper names, and person(s).

In the opening chapter of Didier Eribon's Retour à Reims (2009; English translation: Returning to Reims, 2018), the French philosopher muses on the relationship between the individual and the collective, as well as about the possibility of recovering and reconstructing one's past in auto/biographical form(s). Clearly inspired by Eribon's long-time study of Pierre Bourdieu's ideas and his own investigation of class and sexual habitus, Eribon notes:

The private sphere in even its most intimate manifestations, when it resurfaces in old snapshots, can still serve to reinscribe us in the very particular social location from which we came, in places marked by class, in a topography in which that which you might take as belonging to the most fundamentally personal kinds of relations nonetheless plants you firmly in a collective history, a collective geography. (It is as if tracing any individual genealogy were somehow inseparable from uncovering a social archaeology, a social topology that is there in each of us, one of our most fundamental truths, even if not one of the ones we are most aware of). (2018, p. 18)

The book in which this claim notably manifests itself ${ }^{13}$ is Annie Ernaux's Les Années (2008; English translation: The Years, 2018) - the first of three cases that this paper wishes to address. Although Ernaux's concern with auto/biography can be traced back to 1974 (and her debut novel Les Armoires vides), while her critics have long discussed the question of the author/narrator/character merge in her auto/biographical fiction, as well as the works' resistance to be placed within conventional generic definitions, ${ }^{14}$ it was in 2008 , with the publication of The Years, that Ernaux's ambiguous relationship with the auto/biographical author was most

\footnotetext{
${ }^{11}$ After Lejeune and his four conditions that need to be met by an autobiographical narrative (1989a, p. 4). In Genette's structuralist terminology both aspects that I have selected fall under the category of "voice" (Genette, 1993, p. 68).

${ }^{12}$ Given the fact that an accurate onomastic correlation between the author, narrator, as well as main character was one of the major principles of autofiction stipulated by the genre's originator Serge Doubrovsky, a deliberate lack or violation of this correspondence in the works of Cusk, Heti, Ernaux, Ferrante, Knausgård, and others, makes their unambiguous classification as specimens of autofiction quite controversial and problematic.

${ }^{13}$ According to Alison S. Fell and Edward Welch, Pierre Bourdieu is "Ernaux's most important influence in her understanding of the interaction of self and other in contemporary French society” (2009, p. 4).

${ }^{14}$ Among some major English-language studies dedicated to Ernaux in which the above-mentioned issues are addressed in detail, one should list Lyn Thomas's Annie Ernaux: An Introduction to the Writer and Her Audience (1999); Siobhan McIlvanney's Annie Ernaux: The Return to Origins (2001), and Jennifer Willging's Telling Anxiety: Anxious Narration in the Work of Marguerite Duras, Annie Ernaux, Nathalie Sarraute, and Anne Hébert (2007).
} 
powerfully expressed. It should be noted that one of the means to achieve this referential uncertainty is the writer's defiance regarding the use of the pronoun "I."

Throughout the entire book, a kind of memory narrative which offers an account of the period between Ernaux's birth in 1941 and 2006, the writer consistently refers to herself using the third person pronoun (singular "she") and plural "we"15 - a diegetic solution which makes this volume a kind of autrebiography (Coetzee, 1992, p. 394) or autobiography in the third person (Lejeune, 1989b). "There is no 'I' in what she views as a sort of impersonal autobiography. There is only 'one' and 'we,' as if now it were her turn to tell the story of the time before" (Ernaux, 2018, p. 225) - the narrative concludes (and, simultaneously, provides a meta-reflection on its own discursive status) in one of the final pages of The Years. However, this is just one of the ways in which the relationship between the author, narrator, and character is being scrutinised and ultimately denounced. For example, the narrative repeatedly emphasises the narrator's limited knowledge about her/his character: "Maybe she is gazing at the school years behind her," the narrator states; elsewhere she/he adds: "There is probably nothing on her mind that has to do with political events, crimes, random news items, and all that will later be acknowledged to have shaped the landscape of her childhood" (pp. 36, 37). Most importantly, The Years rejects one of the principal tenets of authorship (and auto/biography), namely individual subjectivity. It achieves this very aim via two means: the very category of the voice which involves both the use of the third person pronouns and abandonment of any onomastic markers of identity, as well as ostensible references to the notion of habitus. In one of the early passages that stipulate the book's poetics (and, consequently, its identity politics) one reads:

Memory was transmitted not only through the stories but through the ways of walking, sitting, talking, laughing, eating, hailing someone, grabbing hold of objects. It passed body to body, over the years, from the remotest countryside of France and other parts of Europe: a heritage unseen in the photos, lying beyond individual difference and the gaps between goodness of some and the wickedness of others. It united family members, neighbours, all those of whom one said "They're people like us," a repertory of habits and gestures shaped by childhoods in the fields and adolescent years in workshops, preceded by other childhoods, all the way back to oblivion. (pp. 31-32)

In Ernaux's book - which has been alternatively labelled, often upon the suggestions of the writer herself, an "ethnotext"16 (ethnotexte), "auto-socio-biography" (auto-socio-biographie), "impersonal autobiography" (autobiographie impersonnelle), or even a "total novel" (roman total) (Sánchez Hernández, 2017, p. 196; Hugueny-Léger, 2018, p. 263; Ernaux, 2018, p. 225; Bacholle-Bošković, 2013, p. 12) - there is no place for the author and her "individual genealogy" which has, instead, been replaced by a "social archaeology." Her "collective autobiography" - the term that has been most widely used to define this piece and other narratives at the confluence of auto/biography and sociology - does not differentiate between family and social narratives which the narrator identifies as "one and the same" (Ernaux, 2018, p. 29) just like it does not differentiate between the individual and the collective, the self and the

15 “[E]verything was told in the 'we' voice and with impersonal pronouns" (Ernaux, 2018, p. 25).

${ }^{16}$ Shirley Jordan writes about Ernaux "turning [in The Years] an objective, auto-ethnographic eye on her intimate experiences and writing "transpersonally"” (2011, p. 138). 
plural, anonymous "we." In The Years, the auto/biographical self (so powerfully associated with the authorial self) has been de-authorised and replaced by the "transpersonal 'I"" (je transpersonnel) (Hugueny-Léger, 2018, p. 263).

Another prominent book of self-writing which radically deconstructs the notion of authorship in our present-day "culture of self-exposure" (Hugueny-Léger, 2017, p. 9) is, the present paper would like to argue, Édouard Louis's debut novel En finir avec Eddy Bellegueule (2014; English translation: The End of Eddy, 2017). This book - a first-person narrative which traces the escape of the titular character from an oppressive childhood spent in Northern France and marked by poverty, violence, and homophobia - is a particularly intriguing study case with regard to the "broadcasting" of the authorial self. On the one hand, upon its publication, the book and its author enjoyed some extraordinary media hype in which the writer's life and personal experiences, and their novelistic rendition were given special prominence (the process which accelerated considerably upon the release of Histoire de la violence [2016; English translation: History of Violence, 2018], an auto/biographical account of Louis's rape). On the other hand, however, The End of Eddy appears to powerfully denounce the very idea of selfwriting, notably manifested by its use of the proper name(s). One should bear in mind that, as Philippe Lejeune rightly observes, it is in the proper name that "the person and discourse are linked even before being joined in the first person" (Lejeune, 1989a, p. 11).

The very tool with which Louis disarms both the regime of auto/biography and authorship is anthroponyms. Édouard Louis, the book's author, and Eddy Bellegueule, the book's young protagonist, are not only two distinct phenomena (one historical, the other fictional). Eddy Bellegueule is also the name of a real-life individual born in Hallencourt in 1992, who, in 2013, officially changed his name to Édouard Louis - in other words, he is the past and nonexistent "self" of the book's author (this identity split is further complicated by insisting on the use of the pronoun "I" throughout the whole book). In the course of the narrative it becomes evident why The End of Eddy is not a work of auto/biography per se. Eddy is "a tough guy's name" (Louis, 2017, p. 14), chosen by the boy's father, in which his class and sexual habitus are inscribed. It is also the name that is synonymous with homophobic victimisation: Bellegueule is "Bellegueule, the homo" (p. 9), "a creature beyond their [his parents'] ken" (p. 18), a "pussy [...] not right in the head" (p. 15), a "fairy" and "faggot" (p. 67) with "fancy ways" and "queenly gestures" (p. 15). It is by no means a coincidence that after the first act of violence, once he has been beaten by his schoolmates, he is forced to disclose his name: Eddy Bellegueule, the victim's name (p. 5). True to its title, The End of Eddy narrates Eddy's demise, his "pass[ing] over to the other side" (p. 91), the process of eradicating the (childlike/working class/"homo") self and preparing the ground for "becoming" (adult/bourgeois/gay) Édouard the operation which begins on the last pages of the book with Eddy's departure from his hometown and arrival at the boarding school. The End of Eddy testifies to a thorough transformation of the self and a radical shift from one habitual code to another (including body habits), from one legal self to another. The key to this interpretation may be found in the motto to the book, a line from Marguerite Duras's ${ }^{17}$ Le Ravissement de Lol V. Stein, which states: "For

\footnotetext{
${ }^{17}$ This reference to Duras is by no means incidental. As Elise Hugueny-Léger demonstrates, Duras is widely considered "a prime example of autofictional writing," while her appearance on the TV show Apostrophes to
} 
the first time my name said out loud means nothing." Indeed, the name "Eddy" is no longer meaningful in extra-diegetic reality; following the legal name change, "Eddy" does not have its real-life referent any more. The auto/biographical author has been erased from the pages of the book and fully transformed into a fictional creation.

Finally, the state of the present-day authorship is also one of major thematic preoccupations of Rachel Cusk's “autofictional" trilogy which is, toutes proportions gardées, simply flooded with writers, with their public and private personas. In Outline (2014), they are the students and fellow-teachers of Fay - Cusk's doppelganger or alter-ego, or surrogate - in an Athensbased creative writing summer course. In Transit (2016) and Kudos (2018), they are fellow speakers at literary festivals and fellow attendees of several literary festivals and seminars.

Cusk is often ruthless in her unfavourable and castigatory portrayal of contemporary authors. This is perhaps best exemplified by the character named Ryan - an arrogant Irish writer whom Faye first meets in Greece (Outline) and who later re-appears at a writers' event in Germany $($ Kudos). Now a best-selling writer (his New York Times bestseller was written under a pseudonym and co-authored by his ex-student), he alludes to Faye remaining a minor writer in the book-selling business:

"Unfortunately," he said, "the economics of it [anthology he put together - author's note] meant we couldn't ask people like yourself for contributions, since the whole point of it was to make money and as I say, we needed the big names for that." (Cusk, 2018, p. 121)

However, I would argue that the most memorable portrayal of authors is provided in the second volume of the trilogy. Julian, one of the writers who is a star guest at a literary festival taking place somewhere in the UK (he calls himself "a festival tart"), speaks openly about his attention-seeking ("All writers are attention seekers" [Cusk, 2016, p. 93]) and about the whole experience of broadcasting the authorial self: "It's like my mum on her two weeks in Lanzarote [...]. Soak up every bit of it while you've got the chance. None of your gradual, even tanning - I'm wanting to get positively barbecued. If this is my moment in the sun, I intend to gorge on it" (p. 88). Elsewhere, he calls himself "a self-publicist" (p. 101). But it is the other panellist, Louis (clearly reminiscent of Karl Ove Knausgård) - similarly to Julian recognised for writing books that have been categorised as autobiographical - that provides a more complex conceptualisation of the author and his/her relationship with their work. Not only does he acknowledge the major tenet of auto/biographical narratives, which he defines as "the ability to deny the truth about oneself - perhaps, almost, the necessity of denying it" (p. 108), but he also emphasises the creation of "a new self" which is attained in the process of becoming a public figure: "He was actively and by small degrees becoming distanced from the person he had been, while becoming by the same small degrees someone new" (p. 104). The metaphor of a cat and a bird which he develops throughout his talk (the former, his "public identifica-

discuss her book L'Amant (1984) in 1984 should be recognised as the moment when " "la Duras' public figure" was created and, more generally, the private sphere of the writer's life entered the public domain in France (2017, pp. 9-10). 
tion" being in conflict and hoping to exert power over with the latter, i.e. his "private identification," which he also associates with the idea of truth ${ }^{18}$ ) corresponds, of course, to the central relationship of the trilogy, namely that between real-life Rachel Cusk and fictional Fay, as well as between Cusk and other characters in the book - all of whom might be seen as "commentaries" 19 on the life of the series' creator. The auto/biographical, authorial self becomes first fictionalised and then compartmentalised into the characters, thus turning the whole trilogy into a series of "delegated performances" - the term that I have borrowed from Clair Bishop's Artificial Hells. By referring to Bishop's other notion of "outsourcing authenticity" (2012, p. 219), one could also describe Cusk's strategy as dependent on the process of "outsourcing" 20 the authorial self.

In conclusion, it needs to be acknowledged that the writings of Annie Ernaux, Édouard Louis, and Rachel Cusk - alongside those by other contemporary "autofictionalists," the ones that have been named in this paper, as well as many more that have been overlooked for reasons of economy - announce and demonstrate the arrival of a new self-writing poetics. Among the major characteristics of this literary practice is, as Jameson accurately observed, a very special preoccupation with the category of the voice - a means through which "autofictional practitioners control the instability - and the omnipresence - of their authorial persona(e), a multiplicity which has expanded the creative space, displacing the authorial centre of gravity, outside the name printed on a written text" (Hugueny-Léger, 2017, p. 15). This poetics is, I would like to argue, best illustrated by the title of the closing volume of Cusk's trilogy, which in the book's diegesis refers to an award given annually to most outstanding students of some unnamed German college and received by Hermann, one of Fay's interlocutors. "Kudos," the word that means "praise" or "glory" and that comes from Greek, neither, of course, appears in a singular form (i.e. kudo), nor is exactly plural, as the confusing presence of what is recognised as the plural suffix would suggest - at least according to the strict grammatical rules and definitions. Its usage, however, allows for both - in particular for the existence of the "fabricated plural" 21 (the kind that would refer to "accolades" or "prizes"). But as Hermann observes, when referring to his mother's use of the word ("the board of directors took the kudos for the festival's success while she did all the work" [2018, p. 98]), kudos is also powerfully suggestive of misappropriation, "of something which might be falsely claimed by someone else" (p. 98). Indeed, quite like the lives of historical authors: Annie Ernaux, Édouard Louis, and Rachel Cusk, which have been misappropriated and (falsely) claimed by their "surrogates."

\footnotetext{
${ }^{18}$ He talks about "playing cat $[\ldots]$ to his own bird" (p. 105).

19 "I was beginning to see my own fears and desires manifested outside myself, was beginning to see in other people's lives a commentary on my own" (Cusk, 2014, p. 75).

${ }^{20}$ Attention should be paid to three functions of outsourcing noted by Bishop which might also be observed in life narratives discussed herein, i.e. "improving performance," "decreasing risk," and "increasing unpredictability" (2012, pp. 219-239).

${ }^{21}$ Interestingly, when talking about the award in the context of "fabricated plural," Hermann emphasises its collective meaning: "the individual has been superseded by the collective" (2018, p. 98) - this, of course, encourages one to see more parallels between Ernaux's and Cusk's self-narratives.
} 


\section{References}

Ali, M. (2017, January). A room of her own: Risky, revolutionary new novel. The New York Times' Sunday Book Review. Retrieved October 30, 2019, from https://www.nytimes.com/2017/01/23/books/review/rachel-cusk-transit.html.

Attlee, A. (2019, May). Fiction of facts. The Times Literary Supplement. Retrieved October 30, 2019, from https://www.the-tls.co.uk/articles/public/autofiction-fiction-of-facts/.

Bacholle-Bošković, M. (2013). Annie Ernaux: de la perte au corps Glorieux. Rennes: Presses universitaires de Rennes.

Barthes, R. (1979). S/Z. (R. Miller, Trans.). London: Cape.

Bennett, A. (2005). The author. London and New York: Routledge.

Bishop, C. (2012). Artificial hells: Participatory art and the politics of spectatorship. London and New York: Verso.

Burke, S. (1992). The death and return of the author: Criticism and subjectivity in Barthes, Foucault and Derrida. Edinburgh: Edinburgh University Press.

Burke, S. (2003). Authorship: From Plato to the postmodern. A reader. Edinburgh: Edinburgh University Press.

Clark, A. (2018, June). Drawn from life: Why have novelists stopped making things up? The Guardian. Retrieved October 30, 2019, from https://www.theguardian.com/books/2018/jun/23/drawn-from-life-why-have-novelists-stopped-making-things-up.

Coetzee, J. M. (1992). Interview. In D. Attwell (Ed.), J.M. Coetzee. Doubling the point: Essays and interviews (pp. 391-395). Cambridge and London: Harvard University Press.

Colonna, V. (2004). Autofictions et autres mythomanies littéraires. Auch: Tristram.

Cusk, R. (2014). Outline. London: Faber and Faber.

Cusk, R. (2016). Transit. London: Jonathan Cape.

Cusk, R. (2018). Kudos. London: Faber and Faber.

Dix, H. (Ed.). (2018a). Autofiction in English. Cham: Palgrave Macmillan. https://doi.org/10.1007/978-3-319-89902-2

Dix, H. (2018b). Introduction: Autofiction in English: The story so far. In H. Dix (Ed.), Autofiction in English (pp. 1-23). Cham: Palgrave Macmillan. https://doi.org/10.1007/978-3-31989902-2_1

Doubrovsky, S. (2001). Fils. Paris: Folio.

Elkin, L. (2018, October). Bad genre: Annie Ernaux, autofiction, and finding a voice. The Paris Review. Retrieved October 30, 2019, from https://www.theparisreview.org/blog/2018/10/26/bad-genre-annie-ernaux-autofiction-and-finding-a-voice/.

Eribon, D. (2018). Returning to Reims (M. Lucey, Trans.). London: Alley Lane.

Fell, A. S., \& Welch, E. (2009). Annie Ernaux: Socio-ethnographer of contemporary France: Introduction. Nottingham French Studies, 48(2), 1-5. https://doi.org/10.3366/nfs.2009-2.001 
Ferrante, E. (2012). My brilliant friend (A. Goldstein, Trans.). New York: Europa Editions. Kindle.

Ferreira-Meyers, K. (2015). Autobiography and autofiction: No need to fight for a place in the limelight, there is space enough for both of these concepts. In K. W. Shands, G. Grillo Mikrut, D. R. Pattanaik, K. Ferreira-Meyers (Eds.), Writing the self: Essays on autobiography and autofiction (pp. 203-218). Södertörns: Södertörns högskola.

Garcia, J. J. E. (1996). Texts: Ontological status, identity, author, audience. Albany: State University of New York Press.

Gasparini, P. (2004). Est-il je? Roman autobiographique et autofiction. Paris: Seuil.

Gatti, C. (2016, October). Elene Ferrante: An answer? The New York Review of Books. Retrieved October 28, 2019, from https://www.nybooks.com/daily/2016/10/02/elena-ferrante-an-answer/.

Genette, G. (1993). Fiction and diction (C. Porter, Trans.). Ithaca and London: Cornell University Press.

Heti, S., \& Cusk, R. (2018, October). Sheila Heti And Rachel Cusk on why memoir is a dead end [Audio podcast]. Canadaland. Retrieved October 30, 2019, from https://www.canadalandshow.com/podcast/sheila-heti-and-rachel-cusk-on-why-memoir-is-a-dead-end/.

Hix, H. L. (1991). Morte d'Author: An autopsy (Arts and their philosophies). Philadelphia: Temple University Press.

Hughes, A. (1999). Heterographies: Sexual difference in French autobiography. Oxford and New York: Berg.

Hugueny-Léger, E. (2017). Broadcasting the self: Autofiction, television and representations of authorship in contemporary French literature. Life Writing, 14(1), 5-18. https://doi.org/10.1080/14484528.2016.1219215

Hugueny-Léger, E. (2018). Annie Ernaux. French Studies: A Quarterly Review, 72(2), 256-269. https://doi.org/10.1093/fs/kny014

Jameson, F. (2018, October). Itemised. London Review of Books. Retrieved November 1, 2019, from https://www.lrb.co.uk/v40/n21/fredric-jameson/itemised.

Jordan, S. (2011). Writing age: Annie Ernaux's Les Années. Forum for Modern Language Studies, 47(2), 138-149. https://doi.org/10.1093/fmls/cqq080

Kusek, R. (2017). Through the looking glass: Writers' memoirs at the turn of the $21^{\text {st }}$ century. Kraków: Jagiellonian University Press.

Lejeune, P. (1989a). The autobiographical pact. In P. J. Eakin (Ed.), Philippe Lejeune: On autobiography (K. Leary, Trans.) (pp. 3-30). Minneapolis: University of Minnesota Press.

Lejeune, P. (1989b). Autobiography in the third person. In P. J. Eakin (Ed.), Philippe Lejeune: On autobiography (K. Leary, Trans.) (pp. 31-47). Minneapolis: University of Minnesota Press.

Louis, É. (2017). The end of Eddy (M. Lucey, Trans.). London: Harvill Sacker.

Lowdon, C. (2018, August). Books: What's autofiction all about? The Sunday Times. Retrieved October 30, 2019, from https://www.thetimes.co.uk/article/books-whats-autofiction-all-about$3 \mathrm{vc} 5012 \mathrm{st}$. 
McIlvanney, S. (2001). Annie Ernaux: The Return to Origins. Liverpool: Liverpool University Press. https://doi.org/10.5949/UPO9781846312571

Nehamas, A. (2002). Writer, text, work, author. In: W. Irwin (Ed.), The death and resurrection of the author? (pp. 95-115). Westport: Greenwood Press.

Rak, J. (2013). Boom! Manufacturing Memoir for the Popular Market. Waterloo: Wilfrid Laurier University Press.

Sánchez Hernández, Á. (2017). L'auto-socio-biographie d'Annie Ernaux, un genre à l'écart. Anales de Filología Francesa, 25, 187-205.

Saunders, M. (2010). Self impression: Life-writing, autobiografiction, and the forms of modern literature. Oxford: Oxford University Press. https://doi.org/10.1093/acprof:oso/9780199579761.001.0001

Savoy, J. (2018). Is Starnone really the author behind Ferrante? Digital Scholarship in the Humanities, 33(4), 902-918. https://doi.org/10.1093/llc/fqy016

Schmitt, A. (2010). Making the case for self-narration against autofiction. a/b: Auto/Biography Studies, 25(1), 122-137. https://doi.org/10.1080/08989575.2010.10815365

Schmitt, A. \& Kjerkegaard, S. (2016). Karl Ove Knausgaard's My Struggle: A real life in a novel. a/b: Auto/Biography Studies, 31(3), 553-579. https://doi.org/10.1080/08989575.2016.1184543

Thomas, L. (1999). Annie Ernaux: An introduction to the writer and her audience. Oxford: Berg.

Vilain, P. (2008). Autofiction (J. Herman, Trans.). In V. Gillet (Ed.), The novelist's lexicon: Writers on the words that define their work (pp. 5-7). New York and Chichester: Columbia University Press. https://doi.org/10.7312/vill15080-006

Vilain, P. (2009). L'Autofiction en théorie. Chatou: Les Éditions de la Transparence.

Wade, F. (2015, July). Interview with Rachel Cusk. The White Review, 14. Retrieved October 30, 2019, from http://www.thewhitereview.org/feature/interview-rachel-cusk/.

Willging, J. (2007). Telling anxiety: Anxious narration in the work of Marguerite Duras, Annie Ernaux, Nathalie Sarraute, and Anne Hébert. Toronto, Buffalo, and London: University of Toronto Press. https://doi.org/10.3138/9781442684850

Worthington, M. (2017). Fiction in the "post-truth" era: The ironic effects of autofiction. Critique: Studies in Contemporary Fiction, 58(5), 471-483. https://doi.org/10.1080/00111619.2017.1331999

Robert Kusek (Ph.D, D.Litt), Jagiellonian University Professor, Department of Comparative Studies in Literature and Culture, Institute of English Studies, Jagiellonian University, Kraków, Poland. His research interests include life writing genres, the contemporary novel in English, new nature writing, queer heritage, as well as a comparative approach to literary studies. He is the author of two monographs, including Through the Looking Glass: Writers' Memoirs at the Turn of the 21 st Century (Jagiellonian University Press, 2017), and several dozen articles published in books, academic journals, and magazines, as well as co-editor of fourteen volumes of articles, most notably Travelling Texts: J.M. Coetzee and Other Writers (Peter 
Lang, 2014). He was a researcher in a number of Polish and international projects - currently he is a principal investigator in the National Science Centre funded project entitled "(Un)accidental Tourists: Polish Literature and Visual Culture in South Africa in the 20th and 21st Centuries." 